\title{
THE IMPLEMENTATION OF THE POLICY ON SCHOOL OPERATIONAL ASSISTANCE (BOS) AT JUNIOR HIGH SCHOOLS IN INDRAGIRI HILIR RIAU INDONESIA
}

\author{
Yesrahmatulah', Iqbal Miftakhul Mujtahid², Sofjan Arifin ${ }^{3}$
}

\begin{abstract}
${ }^{1}$ Graduate Study Program, Universitas Terbuka yesrahmatulah@gmail.com

2Public Administration Study Program, iqbal@ecampus.ut.ac.id

${ }^{3}$ Public Administration Study Program, Universitas Terbuka sofjan@ecampus.ut.ac.id

Received : 11 May 2021

Revised : 07 June 2021

Accepted : 17 June 2021

Published : 21 June 2021

BOS policy is one of the public policies made by the government aiming at improving the quality of human resources as the indicator of the progress of a nation's development. This study aimed at analyzing and describing BOS policy, the implementation of BOS funds, and the supporting factors and inhibiting factors in implementing BOS policy at Junior High Schools in the Tembilahan subdistrict. This study design was qualitative using a descriptive method. The data and information were collected through an observation technique, interview, and documentation. Data analysis was conducted using classification steps, analysis, and data interpretation until the conclusion was drawn. The result showed that the BOS policy was an appropriate and effective public policy for people in general and, particularly, for the school, teaching staff, and the students. Regarding the implementation of the BOS policy at Public Junior High Schools in the Tembilahan sub-district, it was good and met the BOS technical guideline. However, it still had an obstacle that several school activities could not be accommodated using BOS funds. The supporting factors of the BOS policy implementation at Public Junior High Schools in the Tembilahan sub-district were good communication between several relevant parties and the availability of competent human resources. Meanwhile, the inhibiting factors were financial resources and the characteristics of the policy were too rigid in the use in every school.
\end{abstract}

Keywords: policy implementation; Indragiri Hilir; BOS

\section{ABSTRAK}

Kebijakan BOS merupakan salah satu kebijakan publik oleh pemerintah dengan tujuan peningkatan mutu sumber daya manusia yang menjadi indikator kemajuan pembangunan suatu bangsa. Tujuan penelitian ini adalah menganalisis dan mendeskripsikan implementasi kebijakan dana BOS dan menganalisis dan mendeskripsikan faktor-faktor yang mempengaruhi implementasi kebijakan BOS pada Sekolah Menengah Pertama (SMP) Negeri di Kecamatan Tembilahan. Penelitian ini merupakan jenis penelitian kualitatif dengan metode deskriptif. Data dan informasi diperoleh melalui teknik observasi, wawancara dan dokumentasi. Wawancara dilakukan dengan beberapa informan, dengan penentuan informan menggunakan teknik Purposive Sampling, dengan objek penelitian adalah SMP Negeri di Kecamatan Tembilahan. Analisis data dilakukan dengan tahapan klasifikasi, analisis dan interpretasi data sehingga diperoleh suatu kesimpulan. Hasil penelitian menunjukkan bahwa kebijakan BOS merupakan sebuah kebijakan publik yang tepat dan dampaknya sangat dirasakan oleh masyarakat umumnya dan khususnya oleh sekolah, dewan guru dan peserta didik, hal ini sesuai dengan tujuan kebijakan BOS yang termuat dalam Juknis BOS. Dari segi implementasi kebijakan BOS pada SMP Negeri di Kecamatan Tembilahan sudah sangat baik dan sesuai dengan Juknis BOS, walau masih ada kendala berupa beberapa kegiatan sekolah yang belum di akomodir di dana BOS. Adapun faktor pendukung dari implementasi kebijakan BOS pada SMP Negeri di Kecamatan Tembilahan adalah adanya komunikasi yang baik antar berbagai pihak terkait dan tersedianya sumber daya manusia yang kompeten. Sedangkan yang menjadi penghambat dalam implementasi kebijakan BOS pada SMP Negeri di Kecamatan Tembilahan adalah sumber daya finansial dan karakteristik kebijakan yang masih terlalu kaku dalam hal pemanfaatannya pada tiap-tiap sekolah.

Kata Kunci: implementasi kebijakan; Indragiri Hilir; BOS 


\section{INTRODUCTION}

Education is one of the sectors with a big impact on improving the nation's human development. The government as the highest responsible party in a country has issued the public policy supporting the national education vision for actualizing the intellectual and productive Indonesian people with noble characters. One of the programs for implementing public policies is distributing BOS funds to schools. (Hereafter called BOS). The implementation of public policies is an activity of applying a program (Jones, 1991). Further, Van Meter and Van Horn also stated that the activity contains several actions performed by several parties (individuals/state officials or government or private sector) in the policy to achieve the desired goals (Wahab, 1997).

The mechanism of allocating the BOS funds and the usage at schools is regulated in the Regulation of the Indonesia Ministry of Education and Culture Number 3 of 2019 in the Technical Guidance of Regular School Operational Assistance 2019 that regulates the procedure and the responsibility of using regular school operational assistance. The School Operational Assistance policy (BOS) performed by the government gives a positive impact on education in Indonesia. This government policy has been implemented in Indragiri Hilir Regency since July 2006. Indragiri Hilir Regency consists of 12 sub-districts. The total number of junior high schools receiving the BOS funds is 135 schools.

The practice in the field still finds many inappropriate implementations of BOS policy to the SOP/Standard Operational Procedure (BOS technical guidance). Whereas, the SOP (BOS technical guidance) is made to regulate and control as well as direct a certain policy to be implemented based on its path so it will not cause a new problem that violates the law in the future and it leads to achieving the purposes of why the policy is made. From several mass media, there are many cases of abuse in using the allocated funds. Consequently, the distribution of BOS funds does not meet the expectation. Several findings that appeared in the mass media showed that the weaknesses of implementing the School Operational Assistance policy were the management, lacking of transparency in using the BOS funds by the school parties. Besides, in compiling the Treasurer Accountability Report for the use of Operational Funds, the school parties often make mistakes and are late. Therefore, accountability and credibility are still skeptical. In a study by Nurul Hariswati, it was found that the use of the School Operational Assistance policy was inappropriate to the regulation of using BOS funds mentioned in the BOS technical guidance (Hariswati, 2015). It was also found that several schools had not performed the transparency in managing the BOS funds and the education related to the use of BOS funds had not been implemented in the schools (Regina, Soeaidy, \& Ribawanto, 2014) and (Fauzan, 2014). The problems above, based on the preliminary interview on September $24^{\text {th }}$, 2018, along with the Board of Education, were also happened in Indragiri Hilirregency in terms of managing and using the BOS funds. To discover the implementation of this BOS funds policy, the researcher used the implementation model from the theory by Van Meter and Van Horn. The model of a policy implementation process according to Donald S. Van Meter and Carl E. Van Meter Horn emphasizes the characteristics of a policy in each policy implementation and connects it with the policy issue and policy implementation as well as a conceptual model that links the policy to the policy performance.

Based on the explanation above and considering the importance of high-quality education as well as the benefits of the BOS funds, the researcher aimed at 1) Analyzing and describing the BOS policy to the public Junior high schools in Tembilahan Sub-district; 2) Analyzing and describing the implementation of BOS policy at the public Junior high schools in Tembilahan Sub-district, and 3) Analyzing and describing the supporting factors and the inhibiting factors of the BOS policy implementation at the public Junior high schools in Tembilahan Sub-district

\section{RESEARCH METHOD}

This study was Qualitative Research using a descriptive method. The qualitative study is the method to explore and understand the meaning that is considered from social or humanity issues by individuals or a group of people (Creswell, 2009). The sampling technique in determining the source of information was the purposive sampling technique. The source 
of information was from 4 public junior high schools in the Tembilahan sub-district, namely SMPN 1 Tembilahan, SMPN 2 Tembilahan, SMPN 3 Tembilahan, and SMPN 4 Tembilahan, and the informants related to the process of implementing the BOS program, such as the officers of the Board of Education in Indragiri Hilir regency, Executing Officer team of BOS in Indragiri Hilir regency, Headmasters, the school treasurers for BOS, the chairman of teaching staff and the School Committee Chairman of Public Junior High Schools in Tembilahan Sub-district, Indragiri Hilir Regency. The instruments used here were interview transcripts, observation records, and documentation tools, in the form of a camera or handphone, that were shown to some informants. To collect the required data, the following data collection techniques were used: Observation; Interview, and Documentation

The data analysis was done qualitatively; it is the data analysis process conducted by analyzing the data entirely from several sources. The existing data were then classified and compared to their phenomena. Then, it was continued by analyzing the data using descriptive-qualitative analysis, whereby the collected data were classified, analyzed, and interpreted to obtain a conclusion.

\section{RESULT AND DISCUSSION}

\section{The BOS Policy in Tembilahan Sub- district}

Based on the general and specific goals of BOS policy, namely reducing costs or exempting the payments for the students whose parents have less income, no school in this study object that asked the students to do payments. It was found from the interview with some informants in this study. All schools as the object of this study exempted the payments and reduced the school operational costs. It was discovered from the result of the interview with the regency regular BOS team, and after checking it in the field based on the interview findings along with the school regular BOS team, it was confirmed by the school committee as the representative of the people/students' parents. Based on the result of the interview above, it shows that BOS is a public policy as a decision made by a state institution, the government, to solve public issues. Based on the findings in the interview, the purposes of the BOS policy are considered successful. It is in line with the theory stated by Harold D. Laswell and Abraham Kaplan that a policy is a program to achieve directional goals, values, and practices (Lasswel \& Kaplan, 2013).

A public policy is a series of decisions related to realistic, directional, and measurable public interests performed by the government by involving the stakeholders in certain fields leading to a certain goal (Ramdhani \& Ramdhani, 2017). The BOS policy aims to assist the operational funding and non-personnel matters as well as reduce the students' costs on behalf of improving the quality of the learning process at school that will eventually improve the quality of education. Thus, it is in line with the three (3) general goals of BOS mentioned in the BOS technical guidance Number 3 of 2019. The goal achievement is the result of policymaking as the important factor for an organization (Iskandar, 2012).

Based on the explanation from the informants in the interview, observation, and the study of documents above, it can be said that the policy on BOS funds is an appropriate public policy and its impacts can be felt by many people, especially schools, teaching staff, and students. Based on the opinion by Yoyon (Irianto, 2011), a public policy is a series of actions as an instruction to achieve the goals. Public policy can also be defined as a series of activities established and performed or not performed by the government with a certain goal on behalf of all people's importance. The form of the public policy can be laws or regional regulation and others (Ambarsari, 2002).

\section{The Implementation of a Public Policy (BOS) at Junior High Schools in Tembilahan Sub-district}

According to Van Meter and Van Horn (Subarsono, 2011), it is stated that the implementation of a policy is performed by the government or private sector, both individually or in groups, intended to achieve some goals. Six phenomena affect the implementation of a policy in this study, namely:

\section{Standards and Targets of the Policy}

According to Agustino, when the standard and the target of a policy are too ideal (utopian/ 
visionary), they will be difficult to be achieved. To measure the performance of the policy implementation, it certainly determines a certain standard and target that should be achieved by the policy implementers; generally, the performance of a policy is the assessment for the achievement of the standard and target (Agustino, 2016).

Based on the result of the interview, nearly all schools that had been interviewed related to the accountability for the use of BOS funds had met the regulation of the Ministry of Education and Culture and BOS technical guidance, namely the regulation of the Ministry of Education and Culture Number 3 of 2019. In the observation and the study of documents conducted by the researcher, it was found that the schools had some documents, such as a circular letter, the regulation of the Ministry of Education and Culture, and BOS technical guidance, as the guideline in managing and using the BOS funds. In further detail, the standard and target of a policy become one of the reasons for the success of policy implementation. The standard and the goal of a policy are strongly correlated with the implementers' disposition. Consequently, in this study, all junior high schools in Tembilahan subdistrict, in using and managing the regular BOS funds, followed the obvious standard and target of the policy, namely satisfying the regulation of the Ministry of Education and Culture and BOS technical guidance Number 3 of 2019. This result is supported by Van Meter and Van Horn, that to avoid the interpretation that will cause a conflict between implementers, a clear and measurable policy is required (Widodo, 2011).

\section{Resources}

The policy implementation requires support from resources, both human resources and non-human resources. The success of policy implementation strongly depends on the capability in using the available resources (Agustino, 2016). Frank Jefkins in Public Relations, stated that the existence and the influence of limited time, money, and other resources need to be concerned (Jefkins, 1992).

The development of human resources is proven empirically towards the improvement of public service quality (Mujtahid \& Darmi, 2014). Besides human resources, financial resources and time become important considerations in the success of policy implementation. According to Phoebe Wong, et. al., implementing a policy effectively and efficiently requires the process of analyzing and identifying the improvement and the use of available resources (Wong, Ng, Mak, \& Chan, 2015). Based on the result of the observation, interview, and the study of documents, it was shown that the capability of resources in managing and using the BOS funds at Public Junior high schools in the Tembilahan sub-district strongly supported to achieve the goals of the implementation of BOS policy in Tembilahan sub-district; it can be seen from the human resources capacity in completing the activities and making a report of managing and using the regular BOS funds in time. Even though the financial resources could not entirely accommodate the operational and nonpersonnel costs at the schools, it was categorized as well based on its implementation.

\section{Communication among Organizations}

To perform the public policy effectively, Van Meter and Van Horn (Widodo, 2011), stated that the standard of the goals should be understood by individuals (implementers). Communication is an intended activity by the spokesperson or author through a common system, either symbols, signals, or behaviors (Wardhani, Hasiolan, \& Minarsih, 2016).

The communication phenomenon among organizations is identified from the community outreach conducted by the regular BOS team, at both the regency level and school level. Based on the result of the observation, interview, and the study of documents, it was found that communication among organizations related to the implementation of BOS policy by the public junior high schools in Tembilahan sub-district, performed by both the BOS management team at regency level and the BOS management team at a school level to student guardians, people, or other relevant parties, was categorized very good. In with the opinion by Van Meter and Van Horn (Widodo, 2011), the prospect of effective policy implementation is strongly determined by the communication with the implementers of a policy accurately and consistently. Communication becomes one of the key factors for the success of policy implementation (Syarif, Unde, \& Asrul, 2014). 


\section{The Characteristics of Implementers}

The characteristics of implementers including the structure of bureaucracy, norms, and the patterns of a relationship that happens in the bureaucracy will determine the result of the implementation of a program. Therefore, this discussion is inextricably linked to the structure of bureaucracy.

In this study, the result of the study of documents and the interview showed that the phenomenon of implementers' characteristics would be recognized from the implementers' willingness to participate in all rules in the BOS technical guidance. The implementers' characteristics in the implementation of the BOS policy in terms of managing and using the BOS funds at public junior high schools in the Tembilahan sub-district were categorized as very good. It is seen from the competencies of regencylevel regular BOS team and school-level regular BOS team, support from the government and people, and communication openness with outer parties by the regular BOS team; it is in line with the SOP/BOS technical guidance that has been arranged. It is relevant to the statement by Van Meter and Van Horn (Subarsono, 2011), that the characteristics of an organization, determining whether the program is successful or not, consist of competencies, the total staff, legislative and executive supports, the power of organization, the degree of communication open with both outer partiers and the board of policymakers.

\section{Implementers' Disposition}

The implementers' perception in an organization where the policy is implemented can be in the form of rejection, neutrality, and acceptance related to the personal value system, loyalty, personal interest, and the like. According to the opinion by Van Meter and Van Horn (Agustino, 2016), it is stated that acceptance or rejection from the policy implementers strongly affects the success or failure of the public policy implementation. It is extremely possible since the policy is not implemented based on the formulation result from the residents who strongly understand the issues and problems they feel.

The researcher conducted this study by identifying how far the importance of the targeted groups involved in the use and the management of BOS funds and the implementers' readiness in performing the policy. From the result of the interview, it can conclude that the implementers' disposition, related to the implementation of BOS policy at public junior high schools at Tembilahan sub-district in managing and using the BOS funds, is categorized as excellent. Good implementers' disposition will strongly support the implementation of the BOS policy (Fauzi, 2019). The disposition of implementers against the policy implementation will strongly help the process of achieving the goals of the policy implementation (Handani \& Frinaldi, 2020).

\section{Social Environment, Economy, and Politics}

A non-conducive social environment, economy, and politics can be the source of problems from the failure of policy implementation performance. Therefore, the effort for policy implementation requires an external conducive environment. The result of data collection from the informants showed that the level of support from several parties toward the progress of this BOS funds program was related to the involvement of external parties in using and managing the BOS funds. Support or involvement by the school committee as the representative of students' parents in supporting the BOS funds program is high. It is seen from the involvement of the school committee along with the school parties in designing the use and the management of the BOS funds at school.

The implementation of BOS policy through the phenomenon of a social environment, economy, and politics is seen from the result of the observation, the study of documents, and the result of the interview conducted at public junior high schools in the Tembilahan subdistrict, and it has already been good in giving support to the implementation of BOS policy. The social condition, politics, and economy in the public policy are a big concern; even though, the implementation of policy decisions receives a small concern (Septian \& Suryaningsih, 2019). Even though the phenomenon of social condition, economy, and politics supports the success of performing the policy implementation (Handani \& Frinaldi, 2020).

It can conclude that the implementation of the BOS policy at Public junior high schools in the Tembilahan sub-district, based on the 
result of the interview, observation, and the study of documents, uses 6 phenomena. Based on the phenomena above, the implementation of BOS funds at public junior high schools in Tembilahan sub-district, in using and managing the BOS funds, was categorized as good in terms of following the SOP/BOS technical guidance and the regulation of the Ministry of Education and Culture No. 03 of 2019.

\section{The Supporting Factors and the Inhibiting Factors of BOS funds policy at Junior High Schools in Tembilahan Sub- district}

\section{Supporting Factors}

Thefirstsupporting factoris communication. It strongly determined the success of achieving the goals from the implementation of a public policy. Communication is a vital phenomenon that affects the implementation of a public policy. Effective policy implementation will be performed if the decision-makers know the things they will do. In terms of implementing the BOS funds program at public junior high schools in the Tembilahan sub-district, the communication that was performed was between the regencylevel regular BOS team to the school-level regular BOS team and the school-level BOS team to the parents of public junior high school students in Tembilahan sub-district.

Besides communication, another supporting factor in implementing the BOS program at public junior high schools in the Tembilahan sub-district was human resources. It is one of the several phenomena determining the success of the implementation of BOS policy. Good quality human resources in managing BOS funds will make the process of achieving the goals of the policy implementation easier. It is in line with a study by Azis Rachman, that good quality human resources in managing BOS funds can improve the education quality by managing and using the BOS funds in supplying facilities that support the teaching and learning activity (Rachman, 2020). Regarding the BOS program at the regency level and school level, human resources acting as implementers are the schoollevel BOS management team. Providing good knowledge and skills for the BOS management team requires instruction from the municipal board of education through community outreach. The regency board of education is known to perform community outreach to schools that have received BOS funds in the Indragiri Hilir regency.

\section{Inhibiting Factors}

The inhibiting factor in the implementation of the BOS program at public junior high schools in the Tembilahan sub-district was financial resources. First, it was related to the time of disbursement that almost reaches the end of the quarter year. The late disbursement of the BOS funds still occurs. This delay was caused by several schools that had not finished the Treasurer Accountability Report of BOS to the office. Another thing was caused by the change in the school BOS management team due to a certain cause.

Secondly, the nominal fund received by the schools, based on the total student, does not cover the school's operational and nonpersonnel costs. Whereas, the adequacy level, by William N. Dunn, of a policy is related to the effectiveness level for satisfying the needs, values, or the opportunities to solve the problems (Dunn, 2003). The nominal fund received by the public junior high schools in the Tembilahan sub-district did not satisfy and cover the needs and the school condition in the Tembilahan subdistrict. Therefore, the additional fund from the regional government, besides BOS funds, is required to help the school operational costs.

The second inhibiting factor is the characteristics of a policy, namely the existence of BOS technical guidance that is less flexible. The actual BOS technical guidance is the transcript for the implementers in performing the BOS program, however, the existence of BOS technical guidance also inhibits the school parties in using the available BOS funds. The school BOS management team felt that many other components should be covered by the BOS funds.

\section{CONCLUSION AND SUGGESTION}

The policy on the BOS funds at public junior high schools in the Tembilahan subdistrict is an accurate public policy, and its impact can be felt by many people, especially the school parties, teaching staff, and students. 
By seeing the 6 phenomena for the BOS policy implementation according to the theory by Van Mater and Van Horn, namely the standard and target of the policy, resources, communication among organizations and activity reinforcement, implementers' characteristics, implementers' disposition, as and social, economic, and political conditions, at public junior high schools in Tembilahan sub-district, it can conclude that the implementation is excellent even though several obstacles still occur, such as the nominal fund and the legalization in using the BOS funds.

The supporting factors in the implementation of the BOS policy at public junior high schools in the Tembilahan subdistrict are communication and human resources. Meanwhile, the inhibiting factors in the implementation of the BOS policy at public junior high schools in the Tembilahan sub-district are financial resources and the characteristics of a policy.

The result of this study can be an input for the Ministry of Education and Culture and the Ministry of Finance in terms of managing and using the BOS funds at school. Thus, they can make some improvements in terms of the legalization of a policy. This study can be an input for the regional government to cover the remaining school operational costs as the counterpart budget of the BOS funds from the central government.

\section{REFERENCES}

Agustino, L. (2016). Dasar-dasar Kebijakan Publik (Edisi Revisi). Bandung: CV. Alfabeta.

Ambarsari, D. (2002). Kebijakan Publik dan Partisipasi Perempuan. Jakarta: Pattiro.

Creswell, J. W. (2009). Mixed methods procedures. In Research Design: Qualitative, Quantitative and Mixed Method Approaches. California: Thousand Oaks.

Dunn, W. N. (2003). Pengantar Analisis Kebijakan Publik. Yogyakarta: Gadjah Mada University Press.

Fauzan. (2014). Pengaruh Penerapan Good Corporate Governance Terhadap Perilaku Etis Dalam Pengelolaan Dana Bantuan Operasional Sekolah. Jurnal Ekonomi Modernisasi , Vol. 10 No. 3.

Fauzi, M. I. (2019). Implementasi Kebijakan Kelas Olahraga Di Sekolah Menengah Pertama Negeri 3 Pleret. Jurnal Kebijakan Pendidikan, Vol. 8 No. 2.

Handani, M. S., \& Frinaldi, A. (2020). Implementasi Kebijakan Penerimaan Peserta Didik Baru Dengan Sistem Zonasi Pada SMP Negeri di Kota Padang. Jurnal Mahasiswa Ilmu Administrasi Publik, Vol. 2 No. 3.
Hariswati, N. (2015). Analisa Akuntabilitas Dan Transparansi Tentang Implementasi Kebijakan Pengelolaan Bos. Journal of Innovation in Business and Economics, Vol. 6 No. 1 Hal. 75-88.

Irianto, Y. B. (2011). Kebijakan Pembaharuan Pendidikan: Konsep, Teori dan Model. Jakarta: PT. Raja Grafindo Persada.

Iskandar, J. (2012). Kapita Selekta Teori Administrasi Negara. Bandung: Puspaga.

Jefkins, F. (1992). Public Relation. Jakarta: Erlangga.

Jones, C. O. (1991). Pengantar Kebijakan Publik (Public Policy). Penerjemah: Ricky Istamto. (R. Istamto, Trans.) Jakarta: Rajawali Press.

Lasswel, H. D., \& Kaplan, A. (2013). Power And Society: A Framework For Political Inquiry. New Brunswick (U.S.A) and London (U.K): Transaction Publishers.

Mujtahid, I. M., \& Darmi, T. (2014, Desember 03). Analisis Pengembangan Sumber Daya Manusia Dalam Peningkatan Pelayanan Publik Di Pemkot Bengkulu. Retrieved Oktober 03, 2020, from Repository Universitas Terbuka. : http://repository. ut.ac.id/5639/1/2014_36.pdf

Rachman, A. (2020). Evaluasi Kebijakan Dana Bantuan Operasional Sekolah (BOS) Dalam Meningkatkan Mutu Pendidikan di MTS Muhammadiyah Kota Gorontalo. Journal of Economic, Business, and Administration (JEBA), Vol. 1 No. 1.

Ramdhani, A., \& Ramdhani, M. A. (2017). Konsep Umum Pelaksanaan Kebijakan Publik. Jurnal Publik, Vol. 11 No. 01.

Regina, B., Soeaidy, S., \& Ribawanto, H. (2014). Implementasi Kebijakan Bantuan Operasional Sekolah Di Kota Malang (Studi Di Dinas Pendidikan Kota Malang). Jurnal Administrasi Publik (JAP), Vol. 3 No. 1.

Septian, R., \& Suryaningsih, M. (2019). Implementasi Penggunaan Dana Bantuan Operasional Sekolah (BOS) Untuk Pengembangan Guru Dan Fasilitas Sekolah Di SMP Kota Semarang. Journal Of Public Policy And Management Review, Vol. 8 No. 4.

Subarsono, A. (2011). Analisis Kebijakan Publik (Konsep, Teori dan Aplikasi). Yogyakarta: Pustaka Pelajar.

Syarif, A., Unde, A. A., \& Asrul, L. (2014). Pentingnya komunikasi dan Informasi pada Implementasi Kebijakan Penyelenggaraan Penanggulangan Bencana di Kota Makasar . Jurnal Komunikasi KAREBA, Vol. 03 No. 03.

Wahab, A. S. (1997). Analisis Kebijakan Publik, dari Formulasi ke Implementasi Kebijaksaan Negara. Jakarta: Bumi Aksara.

Wardhani, A. P., Hasiolan, L. B., \& Minarsih, M. M. (2016). Pengaruh Lingkungan Kerja, Komunikasi dan Kepemimpinan Terhadap Kinerja Pegawai. Journal of Management, Vol. 02 No. 02.

Widodo, J. (2011). Analisis Kebijakan Publik, Konsep dan Aplikasi Analisis Proses Kebijakan Publik. Malang: Bayu Media Publishing.

Wong, P., Ng, P. M., Mak, C. K., \& Chan, J. K. (2015, Juli 01). Students' choice of sub-degree programs in self-financing higher education institutions in Hong Kong. Retrieved January 16, 2020, from Springer Link: https://link.springer.com/article/10.1007/ s10734-015-9915-5 